\title{
PECULIARITIES OF CARDIOVASCULAR REACTIONS OF ELITE GRECO-ROMAN WRESTLERS TO REPETITIVE DOSED EXERCISE TEST
}

\author{
Alfonsas Buliuolis, Mindaugas Ežerskis, Kristina Poderienė
} Lithuanian Academy of Physical Education, Kaunas, Lithuania

\begin{abstract}
Research background and hypothesis. The synergy of central and peripheral changes while performing easy exercises in repetitive manner should show central or peripheral changes which start increasing and become a trigger for functional mobilization.

Research aim. The aim of this study was to determine the mobilization peculiarities of central and peripheral cardiovascular function in Greco-Roman wrestlers cohort while performing a dosed exercise test in repetitive manner.

Research methods. Greco-Roman wrestlers, sprinters, endurance runners and non-athletes underwent three Roufier tests (30 squats per 45s) with 2 minutes of recovery between them. The changes in the heart rate (HR) and JT interval taken from 12-lead ECG and $\mathrm{O}_{2}$ desaturation $\left(\mathrm{StO}_{2}\right)$ registered by near-infrared spectroscopy were analyzed.

Research results. HR increased and JT interval decreased more and more in both non-athlete cohorts while there were no significant changes in all three athlete cohorts, i. e. we did not find any summing effects of the repetition of workloads. The tendency of increase in $\mathrm{StO}_{2}$ at the second minute after the dosed workload was greater and greater with each consequent repetition of the testing workload in all cohorts.

Discussion and conclusions. We have proved our hypothesis that peripheral changes during repetitive exercising start increasing earlier than the central ones. The dynamics of central and peripheral cardiovascular indices in nonathlete cohorts while repeating a dosed aerobic exercise test every two minutes demonstrates the cumulative effect of physical exertion whereas in elite Greco-Roman wrestlers as well as in other individuals adapted to physical loads functional indices reiterated.
\end{abstract}

Keywords: electrocardiogram, dosed exercise test, oxygen saturation.

\section{INTRODUCTION}

$\mathrm{O}$ ne of the substantial peculiarities of competitive performance and predominant training loads in combat sports is the fluctuating load intensity which can not be planned precisely in advance. Therefore, the peculiarities of mobilization of body functions and fast recovery is an important factor influencing sports performance, so training these peculiarities is a basic principle in athlete's physical and functional training.

At the onset of exercise, cardiovascular system adapts itself with a series of integrated responses to meet the metabolic demands of exercising muscles
(Hughson, Tschakovsky, 1999). The mechanism for exercise hyperemia is a century old enigma (Clifford, 2007) and interrelation between central and peripheral changes still remain of interest in physiology. Since the cardiovascular system is one of the constituent part and a holistic system of the body, the reactions of cardiovascular system to constant-load tests allow assessing the functional capabilities and functional peculiarities of the body (Vainoras, 2002; Perkiomaki, 2003; Van Schuylenbergh et al., 2004). Muscular activity is the trigger of various functional changes and with 
the development of fatigue the enrolment rate of various physiological mechanisms is a dynamical process. We hypothesized that the synergy of central and peripheral changes while performing easy exercises in repetitive manner should show central or peripheral changes which start increasing and become a trigger in response to exercising. The aim of this study was to determine the mobilization peculiarities of central and peripheral cardiovascular function in Greco-Roman wrestler cohort while performing a dosed exercise test in repetitive manner.

\section{RESEARCH METHODS}

The study participants were four cohorts: elite Greco-Roman wrestlers $(n=12)$; endurance runners $(n=12)$; sprint runners $(n=15)$; healthy adult males $(n=15)$ and females $(n=15)$ who were not engaged in any sport training.

The subjects underwent three Roufier exercise tests (30 squats per 45 seconds) with 2 minutes of recovery between them. A computerized ECG analysis system "Kaunas-workload", developed at the Kaunas University of Medicine, Institute of Cardiology, was employed for continuous 12-lead ECG recording. The changes in RR interval or heart rate (HR), JT interval were analyzed.

Near-infrared spectroscopy was employed for the registration of changes in $\mathrm{O}_{2}$ desaturation $\left(\mathrm{StO}_{2}\right)$ in active muscles during exercising. Standard System Model 325 (Hutchinson Technology) device was used for this purpose. The detector for the registration of infrared signal was placed on right leg ( $m$. vastus lateralis) and $\mathrm{StO}_{2}$ measurements were collected continuously every $3.5 \mathrm{~s}$ throughout the entire protocol.

Statistical analysis. All the data were expressed as mean \pm standard error of the mean (SEM). Hypothesis concerning the difference between means was verified using Student $t$ test for independent and dependent variables. For comparison of rank means within the group, Wilcoxon $Z$ criterion for independent variables was used. Difference in means was regarded as statistically significant when error probability with respect to criteria was $\mathrm{p}<0.05$.

\section{RESEARCH RESULTS}

A lot of cardiovascular indices showed the summing effects of workloads while performing the Roufier exercise test. The results obtained during the study showed that values of HR and their dynamics in non-athletes women cohort differed from the ones in other cohorts during the rest and during the performance of all three testing workloads. At the beginning of registration in non-athlete women's cohort the HR was $94.6 \pm$ $3.35 \mathrm{~b} / \mathrm{min}$, in non-athlete men's cohort $-89.4 \pm$ $4.06 \mathrm{~b} / \mathrm{min}$, in sprint cohort $-77.2 \pm 2.93 \mathrm{~b} / \mathrm{min}$, in endurance cohort $-71.2 \pm 3.01 \mathrm{~b} / \mathrm{min}$ and in Greco-Roman wrestlers cohort $-61.0 \pm 3.5 \mathrm{~b} / \mathrm{min}$. The HR increased at the end of the first workload up to $134.3 \pm 5.04 \mathrm{~b} / \mathrm{min}$ in non-athlete women's cohort, up to $125.4 \pm 3.31$ in non-athlete men's cohort, up to $118.6 \pm 3.91 \mathrm{~b} / \mathrm{min}$ in sprint cohort, up to $108.4 \pm 3.4 \mathrm{~b} / \mathrm{min}$ in endurance cohort and up to $109.6 \pm 2.8 \mathrm{~b} / \mathrm{min}$ in Greco-Roman wrestlers sport cohort. These figures and the increase in HR while performing all three testing workloads are presented in Figure 1. The similar increases in HR were observed while the participants of the study performed the second and the third testing workloads comparing the absolute values of HR. The same difference between cohorts was found in the summing effects of the workloads. Figure 1 shows that the HR increased more and more in both non-athlete cohorts while there was no significant increase of maximal values of HR in all three athlete cohorts, i. e. we found no summing effects of the repetition of workloads.

The duration of JT interval decreased at onset of exercising and Figure 2 presents the shortest values of JT interval registered at the end of workloads. The same tendencies were found in comparison to these data. We found no summing effect of repetitive performance of the testing procedure in endurance and Greco-Roman wrestlers cohorts, between significant $(\mathrm{p}<0.05)$ differences were found in both non-athlete cohorts. The sprint cohort data presented in Figure 2 show that there was a further decrease in duration of JT interval found during the second testing workload $(p<0.05)$ but there was no further decrease during the third workload.

The index of peripheral cardiovascular reaction to testing workloads was the dynamics of $\mathrm{StO}_{2}$ in thigh muscles ( $m$. vastus lateralis). At onset of exercising the $\mathrm{StO}_{2}$ decreased but there were no significant differences found between cohorts while comparing the dynamics of $\mathrm{StO}_{2}$ during the workloads. During the recovery after exercising the $\mathrm{StO}_{2}$ recovered and increased more than the baseline registered before the testing procedures. The greatest increase was observed at the end of the second minute after exercising, i. e. close to the repetition of the next 

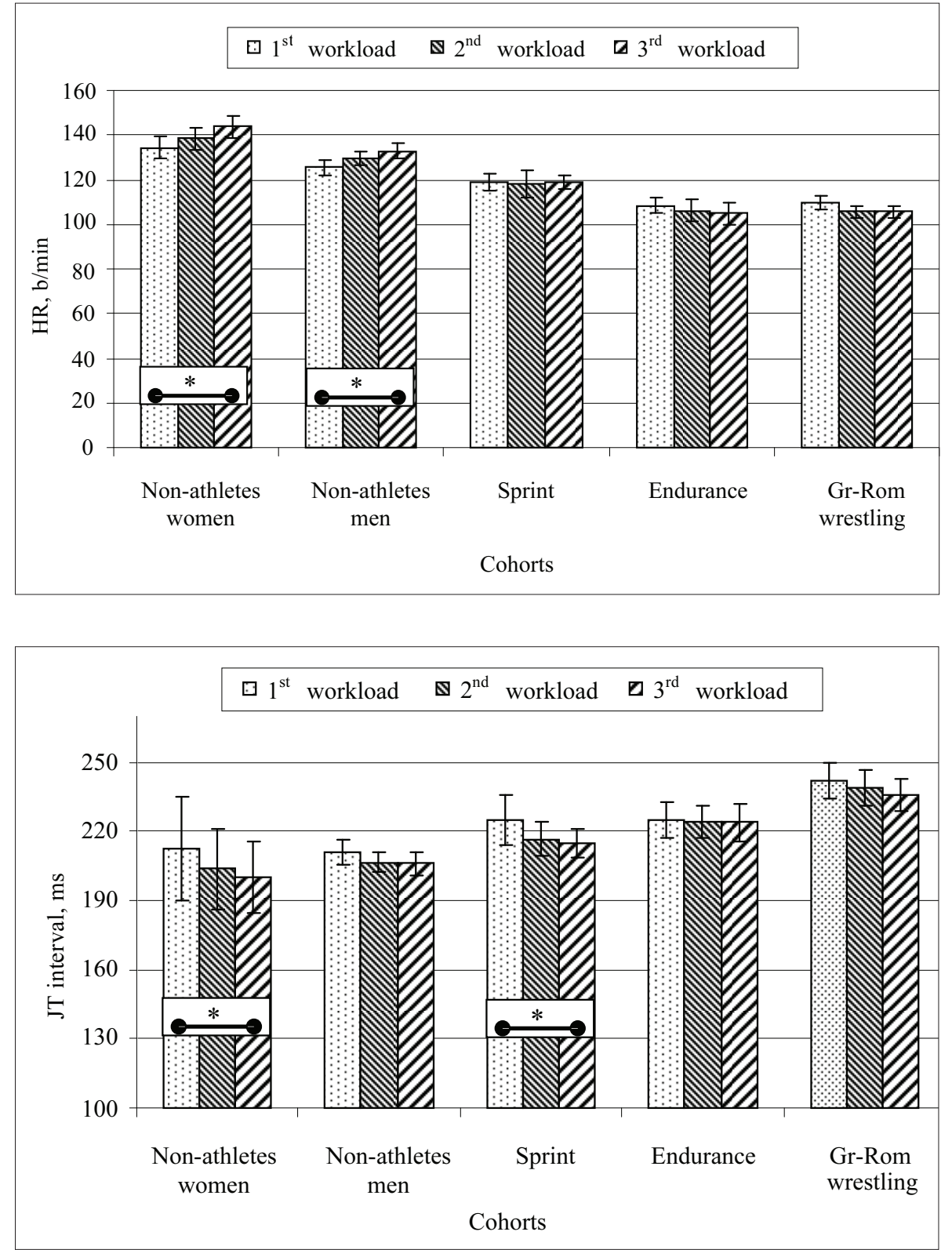

Figure 1. Value of $\mathbf{H R}$ registered at the end of workload while performing three Roufier exercise tests

Note. * - significant difference.

Figure 2. The registered shortest duration of JT interval while performing three Roufier exercise tests

Note. ${ }^{*}$ - significant difference. testing procedure. Figure 3 presents the increase in $\mathrm{StO}_{2}$ in thigh muscles registered before the next testing procedure or 2 minutes after exercising. The results obtained during the study showed that the summing effects of repetitive character exercising could be found in all cohorts. The greatest summing increase was found in the women in non-athlete cohort, i. e. the increase after the first workload was $17.2 \pm 2.7 \%$; after the second $-21.6 \pm 3.1 \%$ and after the third $-27.4 \pm 3.2 \%$. All these changes were significant $(p<0.05)$. The smallest increase along with the performance of repetitive workload was found in endurance cohort (in $3.0 \pm 0.7 \%$ after the first, $3.9 \pm 1.4 \%$ - after the second and $4.7 \pm 1.6 \%-$ after the third workload.) The increase of $\mathrm{StO}_{2}$ in Greco-Roman wrestlers cohort was similar as it was found in the sprint cohort (in $3.9 \pm 0.8 \%$ after the first; $3.7 \pm 0.8 \%$ - after the second and $4.4 \pm 0.8 \%$ after the third workload).

\section{DISCUSSION}

It is well known that adaptation to regular exercising has many advantages including improvement of cardiovascular abilities. Endurance trained athletes, for example medium and long-distance runners, have exceptionally good cardiovascular and functional preparedness, (Карпман и др., 1978; Fagard, 1997; Urhausen et al., 1997; Тхоревский, 2001). For this reason we involved representatives of various kinds of sport in our stydy to compare the central and peripheral cardiovascular reactions at onset of exercising. Results obtained by this study, namely 
Figure 3. Level of oxygen saturation $\left(\mathrm{StO}_{2}\right)$ in thigh muscles (m. vastus lateralis) before the next testing procedure or 2 minutes after exercising.
Note. ${ }^{*}$ - significant difference.



the features of the dynamics of cardiovascular functional indices, are not exclusively new. Vast amount of research has been done evaluating the changes in cardiovascular functional parameters during various repetitive exercises and exercise tests (Карпман и др., 1978; Тхоревский, 2001; Vainoras et al., 2002). The results obtained during this study showed that the changes of central and peripheral cardiovascular indices during dosed exercise test were significantly associated with adaptation and the type of adaptation to physical loads. In both non-athlete's cohorts (women's and men's) all central and peripheral cardiovascular indices while repeating a dosed aerobic exercise test every two minutes demonstrated a cumulative effect of physical exertion and in cohorts adapted to physical loads only peripheral indices had a tendency to increase. This can be explained by different functional preparedness of cardiovascular function (Shephard, 2001; Vainoras, 2002). Active heart muscle during metabolic processes is accelerated from 4 to 5 times, and in order to meet the increased $\mathrm{O}_{2}$ demands, myocardium needs an increase in the coronary circulation system (Žemaitytè, 1996; Тхоревский, 2001). Thus, these differences in cardiovascular response to exercise during dosed workload should be assigned as a result of adaptation to physical loads.

It is known that the size and nature of adaptation, i. e. functional changes in the body systems depend on the type of training and improvements depend on the size and intensity of exposure (Jones, Koppo, 2002). It has been shown that the bigger the size of the heart (left ventricular end-diastolic diameter), the lower the maximum heart rate is the characteristic feature of elite athletes adapted to endurance type of training loads (Карпман и др., 1978; Fagard, 1997; Urhausen et al., 1997; Martinelli et al., 2005). Speed and strength training in general is not a very strong stimulus to myocardium excesses, even in cases when it takes several hours per day (Haykowsky et al., 1998). In general, speed and strength training is not considered as a very strong stimulus for cardiac hypertrophy, even in cases where it lasts for several hours a day (Haykowsky et al., 1998).

At onset of exercising cardiovascular system adapts to a series of integrated responses. The peripheral changes in blood flow and $\mathrm{StO}_{2}$ starts with the beginning of muscular activity but these changes last up to full recovery after exercising (Тхоревский, 2001; Clifford. 2007) and postexercise hyperemia could be an index of intensity of recovery processes (Тхоревский, 2001; Clifford, 2007). Other researchers (Grassi, 2001; Hughson, 2007; Jones, Pole, 2007) have found that the changes in $\mathrm{StO}_{2}$ in muscular tissue is a good index of the intensity of local arterial blood flow. The results obtained in this study showed that the increase in $\mathrm{StO}_{2}$ at the second minute after dosed workload was greater and greater with each next repetition of the workload. So the second significant result of this study is that it has proved our hypothesis that the peripheral changes $\left(\mathrm{StO}_{2}\right)$ during repetitive exercising start to increase earlier than the central ones and the synergic properties of these changes significantly relate to the adaptation to physical loads.

Summing up, the results obtained during the study showed that during dosed exercise tests synergic peculiarities of the dynamics of the central and peripheral functional indices of the 
cardiovascular system were significantly associated with the adaptation and its character to physical loads. During the repetitive dosed tests performed every 2 minutes the dynamics of the majority of central functional indices of the cardiovascular system in non-athletes showed the effect of physical load summation, whereas in the elite Greco-Roman wrestlers and other individuals adapted to physical loads, the functional indices reiterated. This can be explained by the different functional readiness of the studied groups. The second significant result of the study confirmed the idea that the dynamics of peripheral changes $\left(\mathrm{StO}_{2}\right)$ was more important; it influenced the dynamics of central functional indices of the cardiovascular system (indices of ECG). Synergic peculiarities of the dynamics of the cardiovascular system were significantly associated with the adaptation to physical loads.

\section{CONCLUSIONS AND PERSPECTIVES}

During dosed exercise tests the synergic peculiarities of the dynamics of central and peripheral functional indices of the cardiovascular system were significantly linked to the character of the adaptation to physical loads. Dynamics of central and peripheral cardiovascular indices in non-athlete cohorts while repeating a dosed aerobic exercise test every two minutes demonstrates the cumulative effect of physical exertion whereas in elite Greco-Roman wrestlers as well as in other individuals adapted to physical loads functional indices were reiterating.

\section{REFERENCES}

Clifford, P. S. (2007). Skeletal muscle vasodilatation at the onset of exercise. The Journal of Physiology. 15, 583 (Pt 3), 825-833.

Fagard, R. H. (1997). Impact of different sports and training on cardiac structure and function. Clinical Cardiology, 15 (3), 397-412.

Grassi, B. (2001). Regulation of oxygen consumption at the onset of exercise. Is it really controversial? Exercise and Sports Science Reviews, 29, 134-138.

Haykowsky, M. J., Chan, S., Bhambhani, Y. et al. (1998). Effects of combined endurance and strength training on left ventricular morphology in male and female rowers. Canadian Journal of Cardiology, 14 (3), 387-391.

Hughson, R. L. (2007). Regulation of $\mathrm{VO}_{2}$ on Kinetics by $\mathrm{O}_{2}$ Delivery. In Oxygen Uptake Kinetics in Sport, Exercise and Medicine. London and New York: Routlege. P. 185-211.

Hughson, R. L., Tschakovsky, M. E. (1999). Cardiovascular dynamics at the onset of exercise. Medicine and Science in Sports and Exercise, 31 (7), 1005-1010.

Jones, A. M., Koppo, K. (2002). Effect of Training on $\mathrm{VO}_{2}$ Kinetics and Performance. In Oxygen Uptake Kinetics in Sport, Exercise and Medicine. London and New York: Routlege. P. 373-398.

Jones, A. M., Poole, D. C. (2007). Oxygen Uptake Kinetics in Sport, Exercise and Medicine. London and New York: Routlege.

Martinelli, F. S., Chacon-Mikahil, M. P., Martins, L. E. et al. (2005). Heart rate variability in athletes and nonathletes at rest and during head-up tilt. Brailian Journal of Medical and Biological Research, 38 (4), 639-647.

Perkiomaki, S. J. (2003). Nonlinear dynamics of heart rate and repolarization. International Journal of Bioelectromagnetism, 5 (1), 300.

Van Schuylenbergh, R., Eynde, B. V., Hespel, P. (2004). Prediction of sprint triathlon performance from laboratory tests. European Journal of Applied Physiology, 91 (1), 94-99.

Shephard, R. J. (2001). Absolute versus relative intensity of physical activity in a dose-response context. Medicine and Science in Sports and Exercise, 33 (6), 400-418; 419-420.

Urhausen, A., Monz, T., Kindermann, W. (1997). Echocardiographic criteria of physiological left ventricular hypertrophy in combined strength- and endurance-trained arthletes. International Journal of Cardiac Imaging, 13 (1), 43-52.

Vainoras A. (2002). Functional model of human organism reaction to load - evaluation of sportsman training effect. Ugdymas. Kūno kultūra. Sportas, 3, 88-93.

Žemaitytè, D. (1996). Širdies ritmo ir kraujotakos reguliavimo mechanizmu principai. Kardiovaskuline sistema ir sportine veikla. Vilnius. P. 21-41.

Карпман, В. Л., Хрущев, С. В., Борисова, Ю. А. (1978). Сердие и работоспособность спортсмена. Москва: ФиС.

Тхоревский, В. И. (2001). Физиология человека. Москва: ФиС. 


\title{
GRAIKŲ-ROME்NŲ IMTYNININKŲ ŠIRDIES IR KRAUJAGYSLIŲ SISTEMOS REAKCIJOS YPATYBĖS ATLIEKANT KARTOTINIUS DOZUOTO KRŪVIO MËGINIUS
}

\author{
Alfonsas Buliuolis, Mindaugas Ežerskis, Kristina Poderienė \\ Lietuvos kūno kultūros akademija, Kaunas, Lietuva
}

\begin{abstract}
SANTRAUKA
Tyrimo pagrindimas ir hipotezė. Tyrimo hipotezè formuluojama remiantis šiais teiginiais: kartojant subjektyviai lengvus fizinius krūvius, centrinių bei periferiniu širdies ir kraujagyslių sistemos funkcinių rodiklių pokyčiu greitis turetu parodyti, kurie centriniai ar periferiniai mechanizmai yra svarbiausi.

Tikslas - nustatyti graikų-romėnų imtynininkų širdies ir kraujagyslių sistemos funkcinių rodiklių kaitos ypatybes atliekant kartotinius dozuoto fizinio krūvio mėginius.

Metodai. Graikų-romėnų imtynininkai, sprinto ir ištvermès bėgikai, nesportuojantys asmenys atliko tris dozuoto fizinio krūvio mėginius (Rufjè testą, t. y. 30 pritūpimų per $45 \mathrm{~s}$ pailsint dvi minutes tarp krūvių). Norint įvertinti ŠSD ir EKG JT intervalo pokyčius, dvylikos standartinių derivacijų elektrokardiograma (EKG) buvo registruojama nenutrūkstamai. Deguonies issisotinimo $\left(\mathrm{StO}_{2}\right)$ šlaunies raumenyje kaita buvo registruojama neinvazinès artimosios spektroskopijos metodu.

Rezultatai. Kas dvi minutes atliekant kartotinius Rufjẻ mèginius, nesportuojantiems asmenims būdingi nuovargio sumavimosi efektai; sportininkams - mažai išreikšta centrinių ŠKS funkcinių rodiklių reakcija i dozuoto krūvio kartojimus (reakcijų stabilumas) ir tik nedidelè periferinio ŠKS rodiklio $\mathrm{StO}_{2}$ didèjimo tendencija podarbinès hiperemijos fazèje.

Aptarimas ir išvados. Buvo patvirtintas teiginys: atliekant kartotinius Rufjè fizinio krūvio mèginius, periferiniai pokyčiai yra pirmesni ir veikia kitus centrinius ŠKS funkcinius rodiklius. Centrinių ir periferinių ŠKS funkcinių rodikliu kaitos sinerginės ypatybės atliekant dozuotus fizinius krūvius yra reikšmingai susijusios su adaptacijos prie fizinių krūvių pobūdžiu. Kas dvi minutes atliekant kartotinius dozuoto fizinio krūvio mèginius, nesportuojančių asmenų daugumos centrinių ŠKS funkcinių rodiklių kaita sukelia suminį fizinio krūvio efektą, o didelio meistriškumo graikų-romėnų imtynininkų, kaip ir kitų asmenų, kurie adaptavęsi prie fizinių krūvių, funkciniai rodikliai pasikartoja.
\end{abstract}

Raktažodžiai: elektrokardiograma, dozuoto krūvio mėginiai, deguonies įsisotinimas.

Gauta $2011 \mathrm{~m}$. spalio $25 \mathrm{~d}$.

Received on October 25, 2011 